\title{
Correlation Between Serum C-Reactive Protein (CRP) and Soluble CD40 Ligand (sCD40L) with Disease Activity by Modified Rodnan Skin Score (mRSS) in
}

\section{Systemic Sclerosis Patients in Indonesia}

\section{Widi Palupi Ayu Padmandani ${ }^{1}$, Sumartini Dewi ${ }^{2}$, Laniyati Hamijoyo²}

${ }^{1}$ Department of Internal Medicine, ${ }^{2}$ Division of Rheumatology Department of Internal Medicine, Faculty of Medicine Padjajaran University/ Hasan Sadikin General Hospital Bandung

\author{
A R T I C L E I N F O \\ Keywords: \\ Systemic Sclerosis \\ Skin Fibrosis \\ CRP \\ SCD4OL \\ mRSS \\ Corresponding author: \\ Sumartini Dewi

\section{E-mail address: sppd_dewi@yahoo.co.id}

All authors have reviewed and approved the final version of the manuscript.

https://doi.org/10.37275/IJR.v10i1.1

\begin{abstract}
A B S T R A C T
Background: Systemic Sclerosis (SSc) is a chronic autoimmune disease which presents immunological, endothelial dysfunction, skin and organs fibrosis. The inflammatory process is an important pathophysiology of systemic sclerosis. Disease activity assessment using clinical parameters of modified rodnan skin score (mRSS) changes and inflammatory laboratory parameters of C-Reactive Protein (CRP), Erytrocyte Sedimentation Rate (ESR) and soluble CD40 ligand. The European Scleroderma Study Group (EscSG) activity index uses CRP. CRP is higher sensitivity and specificity than ESR ( $80 \%$ and $91.2 \%)$. The study aim isto evaluate the correlation between CRP and SCD4OL with disease activity by mRSS. Methods: This research was a cross-sectional study, and data of mRSS and SCD40L were obtained from the study, " A Double Blind Randomized Controlled Trials of Ciplukan Herbs on Clinical Improvement of Skin Disorders, Inflammatory Process, Immunology and Fibrosis in Scleroderma Patients." CRP examination was done by using the rest samples of the study, conducted in December 2017. Data analysis with Rank-Spearman and Pearson Correlation.Result: There were fifty-eight subjects with mean age $38 \pm 11$ years old. Most of subjects were female $(94.8 \%)$ and with a late disease duration $>2$ years $(74.1$ \%). Subjects consisted of 35 (60.3\%) diffuse SSc and 23 (39.7\%) limited SSc. CRP was measured by turbidimetric immunoassay. Median and range score of CRP serum was $2.89(0.16-17.29) \mathrm{mg} / \mathrm{L}$, while the median of sCD40L was $6457(1018-17976) \mathrm{pg} / \mathrm{mL}$, and the median of mRSS was 17 (4-36). There was no correlation between CRP and sCD40L with mRSS $(r=-0.134, p=0.167$; and $r=0.023, p=0.433)$. Conclusion: There was no correlation between CRP and sCD4OL serum with mRSS in systemic sclerosis patients.
\end{abstract}

\section{Introduction}

Systemic Sclerosis (SSc) is an chronic progressive autoimmune condition involving connective tissue, with inflammation process having major role in pathophysiology and the etiology of this condition are yet to be known for sure.1-3 Pathogenesis triad marked by vasculopathy, autoantibody production and tissue fibrosis.2,4,5 Fibrosis is an interaction result between immune system mediator and inflammation that trigger fibroblast formation causing collagen and extracellular matrix deposit. Fibrosis are the highest cause for morbidity and mortality rate in $\mathrm{SSc} .{ }^{5-8}$

SSc incidences are rare, estimated count 150-300 cases per one million population. One study at Hasan Sadikin General Hospital in year 2014 showed significant increase in patient visit with connective tissue disease from $51.2 \%$ to $63.5 \%$ of total patients visit a year before to after the era of National Health Coverage. ${ }^{9}$ Prognosis on SSc limited type is relatively good with 10 years survival rate more than $70 \%$, while diffuse type has a lower 10 years survival at 40-60\%.10 
SSc affects patient quality of life from all aspects include physical, psychological and economy. Yearly cost for each SSc patient in USA and Canada are estimated around 140-200 million, related with younger age, disease severity level, disease activity and bad health status. 11-13 Polymorphism in the gene level, has a major role in individual vulnerability to SSc. ${ }^{14}$ In accordance to "treat to target" philosophy, it is important to know the exact method to measure disease activity in SSc.11-13

Clinical parameter such as skin fibrosis degree, changes in organ involvement and laboratory parameter which describe inflammation activity, immune activity, fibrosis and vascular can be used to measure disease activity in SSc. ${ }^{15}$ Modified Rodnan Skin Score (mRSS) is a tool in assessing skin fibrosis degree which already proven in several clinical trial and well corelated with skin biopsy. ${ }^{6}$ mRSS have several limitation such as subjectivity aspect of the examiner and not sensitive enough to assess minimum changes although clinically significant, because changes will be seen after 3 to 6 months. 12,13,16 This event cause necessity for serum biological marker to assist mRSS in assessing disease activity more sensitive, objective, quantitatively and faster, especially in fibrosis process as the key factor in SSc and well correlated with mRSS. ${ }^{17,18}$

Inflammation process is among one major role in the pathophysiology of SSc. Biological marker showing inflammation process are Erythrocyte Sedimentation Rate (ESR), C-Reactive Protein (CRP) and soluble CD4O ligand (sCD40L). ESR and CRP are already known as inflammation marker in autoimmune condition to monitor disease activity, CRP is more sensitive than ESR. The European Scleroderma Trials and Research Group (EUSTAR) revised and validate disease activity scoring (EScSG activity index). In the revised scoring, ESR is no longer use, replaced by CRP due to its higher sensitivity and specificity (sensitivity 80\%, specificity 91.2\%). ${ }^{19}$ Previous study also shown that inflammation activity in SSc represent by ESR gave insignificant result to mRSS. 20

C-reactive protein $(\mathrm{CRP})$ is able to measure severity level and disease activity in SSc, as well as describing bad prognosis. ${ }^{15}$ In study done by Ohtsuka et. al. ${ }^{21}$ showed increase hs-CRP on 35\% SSc patients. ${ }^{21}$ Muangchan et. $\mathrm{al}^{5}$ showed increase of CRP on $26 \%$ SSc patients and there was correlation between CRP and mRSS generally in the diffuse type, especially in patient with longer illness duration, although the correlation is moderate $(r=0.4-0.5) \cdot 5,15$

Other biological marker which is already being research is CD40, a cytokine with role in immune system cascade of the SSc pathogenesis. ${ }^{17}$ The CD40CD40L ligand in SSc will activate fibroblast to proliferate and to produce proinflammation cytokine that will start the fibrosis process. Komura et.al.16 report $\mathrm{SCD} 40 \mathrm{~L}$ increased in SSc mostly in limited type. sCD40L is expected to be the inflammation marker correlated with disease activity based on mRSS. ${ }^{16}$ Inflammations process will activate platelet in producing thrombin which will cause secretion of CD40L proinflammation cytokine. This process are the base that CD4OL can be inflammation process biology marker.22 Previous research showed weak positive correlation between SCD40L and mRSS with $r=0.290$ $(\mathrm{p}=0.013) .20$ Other study showed no significant correlation between sCD40L level and mRSS score with $r=0.066(\mathrm{p}=0.346) \cdot{ }^{23}$ Another study showed significant correlation between SCD40L and CRP in restenosis post percutaneous coronary intervention patients, related to pathophysiology of patient endothelium damage. ${ }^{24}$ CD40L expression can influence increasing of CRP level in associate with inflammation process. It means that sCD40L will increase in SSc patients. ${ }^{16}$

Therefore correlation between inflammation marker CRP and SCD40L to mRSS to assess disease activity is still controversial and limited. Study about CRP and sCD40L as inflammation markers linked with gene polymorphism are not yet done in Indonesia, therefore further study is needed to prove CRP and SCD4OL as inflammatory biomarker to monitoring disease activity apart from mRSS.

\section{Research Methods}


Subject

Research subjects are all SSc patients fulfilled ACR/EULAR 2013 criteria, CRP examination was done by using the rest samples of the study done by Dewi S.20 in "Double Blind Clinical trials Extract Ciplukan Herbs on Clinical Improvement of Skin Disorders, Inflammatory Process, Immunology and Fibrosis in Scleroderma Patients", from May 2015 to June 2017, which fulfilled inclusion and exclusion criteria. Inclusion criteria are adult, age 18 years old or above, already diagnosed SSc in out-patient Rheumatology clinic, already have mRSS and SCD40L data. Subjects with comorbid such as rheumatoid arthritis ${ }^{25}$, systemic lupus erythematosus ${ }^{26}$, acute bacterial infection and tuberculosis infection ${ }^{27}$, chronic liver disease 28,29, chronic renal disease ${ }^{30}$, acute coronary syndrome ${ }^{31}$, hypertension ${ }^{32}$, diabetes mellitus ${ }^{33}$, obesity ${ }^{34}$, malignancy ${ }^{35}$, in therapy of estrogen/progestin, or statin are excluded.

Serum sample which fulfilled the criteria are recorded the mRSS score and SCD4OL, then underwent CRP assessment at Clinical Pathology Hasan Sadikin Hospital Laboratory. Hypertension criteria based on Guidelines for the management of arterial hypertension by European Society of Hypertension (ESH) 2013, which is $\geq 140 / 90 \mathrm{mmHg}$ or in therapy of antihypertension medication. ${ }^{32}$ Diabetes mellitus criteria based on guidelines established by Indonesian Endocrinology Society on 2015 that is FBG $\geq 126$ $\mathrm{mg} / \mathrm{dL}$ or 2 -hour PPG $\geq 200 \mathrm{mg} / \mathrm{dL}$, already diagnosed by competent physician or in therapy with anti-diabetic medication. ${ }^{33}$ Obesity criteria based on International Obesity Task Force, The Asia-Pacific Perspective which is Body Mass Index (BMI) $\geq 25 \mathrm{~kg} / \mathrm{m}^{2}$. BMI are stated in $\mathrm{kg} / \mathrm{m}^{2}$ unit. ${ }^{34}$ Acute bacterial infection were diagnosed based on history taking and physical examination in order to obtain information whether there was acute infection event within the last 2 weeks such as upper respiratory tract infection (pharyngitis, tonsilitis, rhinitis bacterialis, acute otitis media), lower respiratory tract infection (acute bronchitis, pneumonia), urinary tract infection (cystitis, uretritis, acute pyelonephritis), skin bacterial infection (erysipelas, cellulitis, pyoderma, subcutaneous abscess), gastrointestinal tract infection (acute dysentery, acute appendicitis, acute pancreatitis, acute peritonitis, liver pyogenic abscess), neuro system infection (meningitis bacterialis, brain abscess), tuberculosis infection or already diagnosed one of the infection by the competent physician. ${ }^{27}$ Rheumatoid arthritis is diagnose based on history taking, assessment in accordance with Indonesian Rheumatology Association (IRA) guidelines on 2014, or already diagnosed as rheumatoid arthritis by competent physician.25 Systemic Lupus Erythematosus diagnosed based on IRA Recommendation on year 2011.26 Chronic liver disease was diagnosed based on history taking, SGPT level assessment based on AASLD criteria year 2015 dan 2016, or already diagnosed.28,29 Chronic Renal Failure was diagnosed based on history taking, physical examination and estimated glomerular filtration rate (eGFR) value in accordance of KDIGO 2012, or already diagnosed chronic renal failure by the competent physician. 30 Acute coronary syndrome (ACS) was diagnosed based on history taking, assessment in accordance with Indonesian Heart Association guidelines on year 2015, or already diagnosed ACS by the competent physician. ${ }^{31}$ Estrogen/progestin or statin medication are the usage in the last one month or less.

\section{CRP concentration}

CRP quantitative measurement from blood serum of research samples done until reaching determined amount. The measurement completed in simultaneously using C-Reactive Protein Extended Range (RCRP) method by Particle Enhanced Turbidimetric Immunoassay (PETIA) technique, cut off normal value $<0.3 \mathrm{mg} / \mathrm{dL} .5$

\section{Statistical Analysis}

This research is a sub-study from a study done by Dewi S. ${ }^{20}$ as an analytic observational study with crosssectional approach, gathers mRSS score and sCD4OL as secondary data, and also assessment of all baseline 
serum samples as biological sample already storage on temperature $-80^{\circ} \mathrm{C}$ at Prodia laboratory. Data analysis using SPSS ver.20. Normalization data using Kolmogorov Smirnov test. Characteristics data are presented in mean and standard deviation if normally distributed or in median and range if not normally distributed. Data analysis using two methods univariate and bivariate analysis. Bivariate analysis with Pearson for data distributed normally or Rank Spearman for data distributed not normal.

\section{Results}

From the total of 61 patients, there were 58 patients fulfilled the inclusion criteria. Medical record tracking is done to obtained data regarding early condition of the subjects, prior medication taken, or any comorbid disease that could make the patient excluded from the analysis. Next step is processing blood sample that already storage in less than a year in -80 o C for CRP quantitative assessment at clinical pathology Hasan Sadikin Hospital laboratory. The data collected are then analyzed and presented in the form of tables and graphic.

Based on Kolmogorov-Smirnov test of normality result with Lilliefors Significance Correction obtained that SCD40L value and mRSS had normal distribution, while CRP value were not normally distributed $(\mathrm{p}=<$ 0,001).

Most of research subject are female with ratio 27:1. Mean age when first disease onset is $38 \pm 11$ years old. Most of the subject were diffuse type 35 subjects (60.3\%), and mostly already diagnosed over 2 years, 43 subjects $(74.1 \%)$.

Table 2 present subjects characteristic based on cutaneous classification namely SSc diffuse type and limited type. Both type has significant different in mRSS score, while sCD40L and CRP has no significant difference.

Table 1. Study Basic Characteristic Data

\begin{tabular}{|c|c|c|}
\hline \multirow[b]{2}{*}{ Characteristic (unit) } & \multicolumn{2}{|c|}{$\mathbf{N}=\mathbf{5 8}$} \\
\hline & n (\%) & $\begin{array}{c}\text { Mean } \pm \text { SD or } \\
\text { Median (min-max) }\end{array}$ \\
\hline Age (year old) & & $38 \pm 11$ \\
\hline \multicolumn{3}{|l|}{ Gender } \\
\hline Male & $3(5,2)$ & \\
\hline Female & $55(94,8)$ & \\
\hline \multicolumn{3}{|l|}{ Type systemic sclerosis } \\
\hline Limited & $23(39,7)$ & \\
\hline Diffuse & $35(60,3)$ & \\
\hline \multicolumn{3}{|l|}{ Illness duration } \\
\hline$\leq 2$ year & $15(25,9)$ & \\
\hline$>2$ year & $43(74,1)$ & \\
\hline BMI $\left(\mathbf{k g} / \mathbf{m}^{2}\right)$ & & $20,29 \pm 3,19$ \\
\hline \multicolumn{3}{|l|}{ Medication history } \\
\hline Methotrexate & $51(87,9)$ & \\
\hline Steroid & $43(74,1)$ & \\
\hline Cyclophosphamide & $1(1,7)$ & \\
\hline Calcium channel blocker & $23(39,7)$ & \\
\hline Aspilet & $26(44,8)$ & \\
\hline Ciplukan herb & $51(87,9)$ & \\
\hline \multicolumn{3}{|l|}{ Duration receiving medication } \\
\hline Methotrexate & & $24(1-84)$ \\
\hline Steroid & & $22(1-67)$ \\
\hline Cyclophosphamide & & 7 \\
\hline Aspilet & & $24(2-72)$ \\
\hline \multicolumn{3}{|l|}{ Laboratory result } \\
\hline Haemoglobin (g/dL) & & $12,7 \pm 1,1$ \\
\hline Leukosit (/UL) & & $8200(3670-19400)$ \\
\hline SGPT (U/L) & & $12(5-42)$ \\
\hline GDS(mg/dl) & & $88(66-148)$ \\
\hline eLFG $\left(\mathrm{mL} / \mathrm{min} / 1,73 \mathrm{~m}^{2}\right)$ & & $110,9(30,9-172,2)$ \\
\hline Kreatinin $(\mathrm{mg} / \mathrm{dL})$ & & $0,67(0,28-1,92)$ \\
\hline ESR (mm/hour) & & $37 \pm 22$ \\
\hline
\end{tabular}


Note: $\mathrm{n}=$ frequency $\%=$ percentage, $\mathrm{SD}=$ Standard Deviation, $\mathrm{N}=$ total subjects, $\mathrm{SGPT}=$ Serum Glutamic Oxaloacetic Transaminase (SGPT), RBG=Random Blood Glucose, eGFR= estimated-Glomerulus Filtration Rate Glomerulus, $\mathrm{ESR}=$ Erytrocyte Sedimentation Rate, $\mathrm{CRP}=C$-reactive protein

Table 2. Different between Systemic Sclerosis Limited Type and Diffuse Type

\begin{tabular}{|c|c|c|c|}
\hline \multirow[b]{2}{*}{ Variable } & \multicolumn{2}{|c|}{ Systemic Sclerosis Type } & \multirow[b]{2}{*}{ p-value } \\
\hline & $\begin{array}{c}\text { Limited } \\
\mathbf{n}=\mathbf{2 3} \\
\end{array}$ & $\begin{array}{c}\text { Diffuse } \\
\mathrm{n}=35\end{array}$ & \\
\hline MRSS (median (range)) & $12(4-36)$ & $23(9-34)$ & $<0.001^{*}$ \\
\hline sCD40L (mean $\pm S D$ ) & $6240 \pm 2221$ & $6732 \pm 3908$ & 0.586 \\
\hline CRP (median (range)) & $0.220(0.016-1.729)$ & $0.360(0.040-1.391)$ & 0.164 \\
\hline
\end{tabular}

Note: *significant $p$-value $<0.05$

Figure 1. Scatter Diagram Correlation of CRP and sCD40L with mRSS

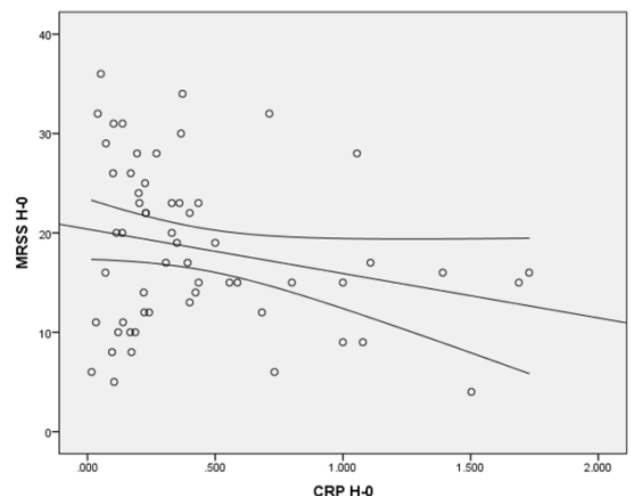

\section{DISCUSSION}

Subjects age mean on first onset of SSc were $38 \pm$ 11 years, this result were coherence with SSc onset, higher on the 4-5 decade of life, other literature said higher on the 3-4 decades of life. ${ }^{25,26}$ Mean age different compared with Allanore et al. ${ }^{13}$ Fifty subjects were $57 \pm$ 11 years and Alba et al. ${ }^{73}$ on 1037 SSc patients in Spain, which most onset happen in age range 20-50 years old, with mean $45 \pm 15$ years. Different age on both population can be happen due to different race and gene polymorphism so that SSc event are more likely happen in older population in Caucasian population compared with Asia. ${ }^{14}$ Study in Japan done by Komura et al. ${ }^{16}$ from 49 subjects that is $51.4 \pm 15.6$ years old. Difference in age between the research with Komura et al. ${ }^{16}$ although both were Asian race, it might be influenced by the gene polymorphism. Other factors that influence gene polymorphism are familial and

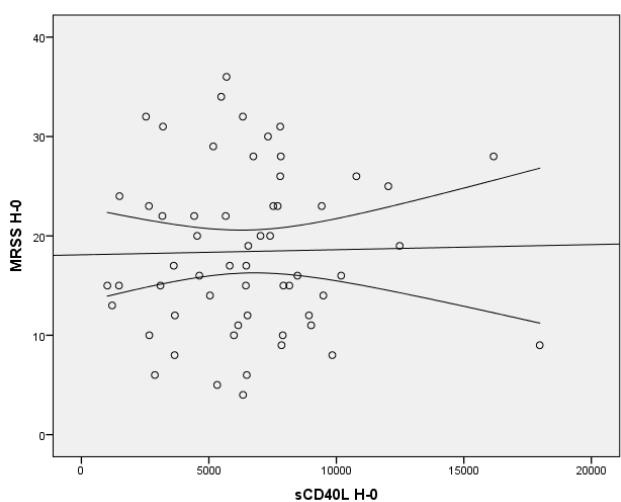

geography. ${ }^{14}$

Most of the subjects were female (94.8\%) with ratio 27 : 1. These results were resembling with the epidemiology of SSc, SSc is more common in female. ${ }^{3,4}$ Similar result also found in a study in Asia done by Komura et.al ${ }^{16}$ that is $92 \%$. Other results in Asian race were female with ratio $9: 1$ done by Mulla et al. ${ }^{36}$. The study result show more female ratio compared with in US that is $3-5: 1.1,37$ Overall from allprevious studies, majority subjects were female, it were related with the specificity SSc antibody that noticeable in female such as anticardiolipin antibody (ACA) found positive in around 92-95\% female, it was also happen with antitopo I antibody around $83 \% .^{3}$

Most of the study subjects 35 (60.3\%) were diffuse type SSc, while 23 subjects (39.7\%) were limited type SSc. Similar result found in Komura et al study. 16 more patients were diffuse type (27 patients), while limited 
type only in 22 patients. Diffuse skin involvement in majority patients (71-87\%) have strong correlation with the existence of anti topo-I and anti-fibroblas antibodies. About $37-60 \%$ diffuse type patients tipe diffuse carried anti-topo I antibody, while limited type is less from $10 \%$. This antibody can influence to disease activity, skin severity level and respond to immunosuppressant medication such as corticosteroids. ${ }^{3}$ Several antibody test which are more specific for SSc namely anticentromere, could be found in 40-50\% diffuse type patients and 5-10\% limited type. While antitopoisomerase (Scl-70) could be found in $30-35 \%$ diffuse type patients and $10-20 \%$ in limited type. 4

Study subjects with disease period $>2$ years were 43 subjects $(74.1 \%)$, while subjects $\leq 2$ years were 15 subjects (25.9\%). Similar with Allanore et al. ${ }^{13}$ which had subjects with disease period $>2$ years were 32 subjects (64\%). Study result showed a shorter period done by Walker et al.38 in Canada with mean duration 14.8 years. Mulla et al. ${ }^{36}$ compared disease period Caucasian and Asia patients, results obtained that Caucasian have mean of period duration 8.9 years, while Asia have mean in 7.3 years. Based on organ involvement timeline, SSc stage are divided into 2 phase namely early (first 2 years) and late (> 2 years). ${ }^{3}$ Study result showed shorter period can be due to time of SSc diagnose establishment were far later from the first symptom.

Medication given to the subjects are varied, mostly are methotrexate (87.9\%), followed by steroid $(74.1 \%)$, aspilet (44.8\%), ciplukan (50\%) and Calcium channel blocker $(39,7 \%)$. While others underwent chemotherapy were only $1.7 \%$. Therapy given to the subjects are in line with the newest SSc management, whereas therapy is not a monotherapy but also a combination therapy to treat immune respond, vascular disease, and body tissue fibrosis. ${ }^{39}$ DMARDs used as choice of therapy are methotrexate, d-penicillamine, azathioprine, MMF and cyclophosphamide, with its rule as immunesuppressant therapy in SSc. 39

Based on assessment to mRSS score, median of mRSS score was 17 . While in study done by
Muangchan et al. ${ }^{5}$ there was no significant different in CRP and mRSS in "early" or "late", no changes in mRSS score can be followed regarding with or without changes of CRP. mRSS is a validated tool to access fibrosis degree, which can be utilized to monitor disease progression also skin fibrosis response to therapy received. mRSS monitoring based on disease course from longitudinal study showed that mRSS will change after 3-6 months of therapy. 40 Result of this study showed significant differentiation in mRSS score, in SSc limited type subjects had median mRSS score 12 , while median mRSS score in diffuse type subjects was 23 with $\mathrm{p}$ value $<0.001$. In Muangchan et al. 5 mRSS mean score in limited type is 5,94 $\pm 5,07$, and in diffuse type is $18,34 \pm 10,29$. According National Institute of Health $(\mathrm{NIH})$, mRSS describes abnormality which are more subjective and semiquantitative to skin density. At this moment mRSS are validated to use in clinical practices and therapy evaluation, also have well correlation with skin biopsy. Median sCD40L concentration in this study was $6.457 \mathrm{pg} / \mathrm{mL}$ with range from 1.018 to $17.976 \mathrm{pg} / \mathrm{mL}$. This value show sCD40L on the study subjects was higher than control in study done by Allanore et al. ${ }^{13}$ which is median 79 (50-118) $\mathrm{pg} / \mathrm{mL}$ and higher compared with the subject in Allanore et al.13 with median 495 (10-2.690) pg/mL. Different results can be caused by this study used cross-sectional method, involved old patients whom already under treatment with immunosuppressants or still have high disease activity despite already receive therapy, while Allanore et al.13 used prospective method and exclusion done to subjects who received immunosuppressant and vasodilator medication.

CRP examination method in this study is Particle Enhanced Turbidimetric Immunoassay (PETIA), results show median $0.289 \mathrm{mg} / \mathrm{dL}(2.89 \mathrm{mg} / \mathrm{L})$ with range $0.016 \mathrm{mg} / \mathrm{dl}$ (0.1 mg/L)-1.729 mg/dl (17.29 mg/L), and cut off the normal value was $<0.3 \mathrm{mg} / \mathrm{dl}<<$ $\mathrm{mg} / \mathrm{L})$. There were 29 subjects (50\%) with elevated CRP concentration level, and there was no different either diffuse type nor limited type. CRP concentration were not significantly different in diffuse type nor limited type with median CRP $2.2 \mathrm{mg} / \mathrm{L}$ in limited type and 3.6 
$\mathrm{mg} / \mathrm{L}$ in diffuse type $(\mathrm{p}=0.164)$. Similar results obtained by Alekprov et al. ${ }^{41}$ that no different between diffuse and limited type. These event might be happen due to limited sample size, in the study only 59 samples not fulfilled the minimum sample size, so as Alekprov et al. ${ }^{41}$ with only 20 samples. Muangchan et al. ${ }^{5}$ obtained median CRP level is $3.60 \mathrm{mg} / \mathrm{L}$, and there was significant different between diffuse and limited type, whereas increased CRP concentration mostly in diffuse type with duration of disease less than 2 years. . Different results of this studies might be happen due to different of total study samples and CRP examination method, while in Muangchan et al. ${ }^{5}$ study, total sample is bigger, confounding variable that could affect CRP concentration were excluded and also homogeneity are done such as medication history. Therefore, there was different method in CRP examination, in Muangchan et al. 5 the cutoff point used are high if CRP $>8 \mathrm{mg} / \mathrm{L}$, while in our study the cut off point used is $>3 \mathrm{mg} / \mathrm{L}$.

In this study, CRP increased in 50\% patients, tit showed that CRP concentration in SSc patients can be permanent due to inflammation process, immunity, endothel damage and fibrosis cascade producing proinflammation cytokine and profibrotic, so that exacerbation, worsening of fibrosis reaction and remodeling process did not happen (vicious cycle). ${ }^{11,30}$ However, this result was not correlated with mRSS, this may be caused wide range of CRP concentration $(0.1-$ $17.29 \mathrm{mg} / \mathrm{L}$ ). The wide range may be happened due to that the subjects were old patients with different type of therapy, medication dosage, and period receiving medication. The other factor which might be influence to CRP concentration is different refrozen process in each sample during study. Refrozen process can change CRP structure from pentamer to monomer, and refrozen on each sample are different so this effect the CRP concentration. ${ }^{51}$ Refrozen process (sample already expose to room temperature from the freezer, then refroze), and CRP level wide range, may also influence correlation results. Based on literature, refrozen process should be avoided because this process can change CRP structure and affect to the results. Sample storage in the study were in accordance with literature that the serum will be stable for more than 10 years if storage on below $-70^{\circ} \mathrm{C} .42$

Bivariate correlation analysis between CRP and mRSS showed that there was no correlation $r=-0.139$ dan $\mathrm{p}=0.149$. This result was different with previous study from Muangchan et al. ${ }^{5}$ on 1043 subjects that there was positive significant correlation between the high CRP concentration to disease activity in SSc, based on mRSS scoring ( $p<0,01)$. Liu et al. ${ }^{43}$ study on 266 patients showed significant correlation between CRP concentration with mRSS ( $\mathrm{p}=0.018)$ after excluded patients in immune-suppressants therapy. Ohtsuka et al.21 reported that hs-CRP concentration increases in 35\% SSc patients with unknown etiology, however it was estimated related to cytokine production include IL-6 and TNF-a. IL-6 concentrations showed intermediate correlation with hsCRP concentration $(\mathrm{r}=$ $0.69) .21$

There is no correlation between CRP and mRSS might be caused by many confounding factors. ${ }^{5}$ In this study, all subjects receive immune-suppressant medication such as cyclophosphamide, methotrexate, and medication with anti-inflammation effect namely steroid and ciplukan herb. Those medication can reduce mRSS score and CRP level. Mysler et al. ${ }^{44}$ study showed a dose of prednison $5 \mathrm{mg}$ per day significantly reduce CRP level $(\mathrm{p}<0.001)$. Systemic glucocorticoid reduce CRP concentration and IL-6.45 Glucocorticoid suppress activity of interleukin, chemokine, cytokine, TNFa and macrophage. ${ }^{2,29}$

Other factors which probably influence to different result compared to other study were total study subjects and different method used. Muangchan et al. 5 study had 1043 subjects, while Liu et al.43 study had 266 subjects, both use prospective cohort approach and a multicenter study.

Another condition which may cause no correlation between CRP level and mRSS score is tissue damage process is permanent. Disease activity in SSc can be assessed from CRP level changes when high disease activity in early stage and fluctuated during the disease course, so according to study done by Nagy et al.46 monitoring of CRP level will assist to evaluate the 
medication efficacy, however CRP level are easily influenced by several condition such as acute bacterial infection or immune-suppressant and antiinflammation medication which mostly used by the subjects, although in SSc, CRP level can be constant as respond from fibrosis. ${ }^{21} \mathrm{mRSS}$ scoring done to evaluate tissue damage due to fibrosis and the assessment of skin fibrosis respond to new therapy can be done and evaluate at least after 3 months, this result correspond with clinical trial done by Khanna et al. 47 that mRSS score does not have significant changes if assessed less than 3 months. Rapid changes of the disease activity are not aligned with tissue damage although medication was already givenit caused the difficulty to get the correlation between both.

Correlation analysis result between $\mathrm{SCD} 40 \mathrm{~L}$ and mRSS showed that there was no correlation between sCD40L level and mRSS score $(r=0.009, p=0.475)$. This result match with study done by Allanore et al.13 whom stated that $\mathrm{SCD} 40 \mathrm{~L}$ concentration were not correlated with mRSS score and study done by Salim et al.23 showed that sCD40L concentration were not significantly correlated with $\operatorname{mRSS}(\mathrm{r}=0.066, \mathrm{p}=$ 0.346). These result did not support theory that sCD40L express fibroblast activation and inflammation process in SSc. ${ }^{13}$ Although several study showed that this event is influenced by fibroblast inhibition by Th2 lymphocyte involving CD4OL which included in superfamily of Tumor Necrosis Factor, whereas more further investigation of this process are required. 48

This results? was different compared with result obtained by Fukasawa et al. ${ }^{49}$ whom reported that there was positive correlation between sCD40L level with mRSS, although there was no significant different between diffuse type nor limited type. sCD40L and mRSS correlation are more significant in shorter disease periods ( $<2$ years), Yan et al.24 additionally reported that there was significant correlation between SCD40L and CRP in patients restenosis post percutaneous coronary intervention, associated with endothel damage pathophysiology. ${ }^{24}$ CD40L expression can stimulate CRP surge related with inflammation process. SCD4OL increased in SSc patients. ${ }^{16}$
Different result compared to previous study were likely caused by different type of subjects which is most of the subject already had the disease over than 2 years, sCD40L increase mainly in early stage of disease as sort out in the study done by Fukasawa et.al. 49 that CD40 plays important role in SSc early abnormalities, include overproduction of cytokine, tissue fibrosis and vascular damage. CD40L expression on T-cell that activated by peripheral lymphocyte are significantly higher in fibroblast on patients with early stage SSc and the interaction between both fibroblast and T-cell have role in early stage fibrosis on the tissue.16,48

Most of the subjects were old patient who already received therapy, this also influenceds CD40L level. Methotrexate is frequently used by subject in Hasan Sadikin Hospital, Methotrexate effects to body immune system were decreasing pro-inflammatory cytokine, extracellular adenosis release, inhibition on T-cell activation. T-cell activation inhibition in SSc may decrease CD40L expression therefore decrease SCD40L level in the serum. ${ }^{48}$ Methotrexate can also affect CD40L through inhibition of cell production and ligation proinflammation cytokines such as TNF, IL-6, IL-8, IL-1 produced by monocyte, macrophage and lymphocyte.50 Second, the most used therapy are steroid, steroid can induce lymphocyte apoptosis, mainly T-lymphocyte in the peripheral lymphoid organ and decrease T-lymphocyte migration to the inflamed tissue so that autoantibody production by the lymphocyte are decreased and this may influence CD40L score. 51

Fifty percent of the subjects received ciplukan herb therapy, ciplukan inhibit lymphocyte and monocyte on its function but did not affect the amount of it, especially T-lymphocyte through inhibiting IL-2, Il-6 and IL-7 production by the lymphocyte. Ciplukan also inhibit macrophage activation in the inflamed tissue. 52

Bivariate analysis both CRP and SCD40L in this study did not reveal correlation of disease activity measure based on fibrosis level using mRSS. This could be happen due to the subjects in the study had SSc more than 2 years. CRP and sCD40L can increase mostly on early disease stage due to inflammation 
factor which was dominantly influenced by body immune, on the other hand, longer period of the disease, the tissue damage caused by fibrosis were more prominent. Increased level of CRP and SCD4OL can be fluctuates in accordance with disease activity. 3,5,16,48 The lack of correlation between CRP and SCD40L with mRSS can explain that decreasing of CRP will decrease inflammatory activity wich does not improve mRSS score in SSc. Inflammation process are less dominant compared with other process such as immune process or oxidative stress in influencing fibrosis cascade. 15,30

There were several limitations in the study which affect to the result such as1) Subjects were old patient, many confounding factors such as varied medication history, 2) Most of the subjects already received steroid therapy or any other immune suppressant affecting CRP level, 3) Most of research subject had already received DMARD methotrexate which can inhibit T-cell activation so that will affect to CRP and sCD40L level.

\section{CONCLUSION}

There is no correlation for CRP level to mRSS also between SCD40L level to mRSS in SSc patients. A study regarding $\mathrm{CRP}$ and $\mathrm{SCD} 40 \mathrm{~L}$ serum level related with disease activities based on mRSS score are better done in new patient whom not yet received any medication, and prospectively cohort monitored from starting the therapy until completion. CRP and SCD40L level measurement are not yet can be recommended as tool to help clinician in assessing disease activity based on skin fibrosis in SSc patients. CRP and SCD4OL level interpretation should notice factors that might be affecting such as DMARD or steroid therapy, period of disease, also blood serum sample storage, if using storage biological samples. Fibrosis degree assessment using mRSS should be socialize through training and workshop to enhance physician skill to asses therapy response in SSc patients.

\section{REFERENCES}

1. Gabrielli A, Avvedimento EV, and Krieg T. Scleroderma. N Engl J Med. 2009;360(19):19892003.
2. Varga J, and Denton C. Systemic Sclerosis and the Scleroderma-Spectrum Disorders. In: Firestein G, Budd R, Edward D, Harris J, McInnes I, Ruddy S, et al., editor. Kelley's Textbook of Rheumatology. 8th Ed. Philadelphia: Saunders Elsevier; 2009. p.1311-52.

3. Varga J. Systemic Sclerosis (Scleroderma) and Related Disorders. In: Kasper D, Hauser S, Jameson J, Fauci A, Longo D, and Loscalzo J, editor. Harrison's Principles of Internal Medicine. 19th Ed. New York: McGraw-Hill; 2015. p.2154-65.

4. Hamijoyo L. Sklerosis Sistemik. In: Setiati S, Alwi I, Sudoyo A, Setiyohadi B, and Syam A, editor. Buku Ajar Ilmu Penyakit Dalam. 6th Ed. Jakarta: Interna Publisihing; 2014. p.3277-86.

5. Muangchan C, Harding S, Khimdas S, Bonner A, Baron M, et al. Association of C-Reactive Protein with High Disease Activity in Systemic Sclerosis: Results From the Canadian Scleroderma Research Group. Arthritis Care Res (Hoboken). 2012;64(9):1405-14.

6. Mayes M, and Assasi S. Classification and Epidemiology of Scleroderma. Dalam: Hochberg M, Silman A, Smolen J, Weinblatt M, and Weisman M, editor. Rheumatology (Oxford). 6th Ed. Philadelphia: Elsevier; 2015. p.1153-7.

7. Abraham DJ, Krieg T, Distler J, and Distler O. Overview of Pathogenesis of Systemic Sclerosis. Rheumatology (Oxford). 2009;48(3):33-7.

8. Haustein U. Systemic Sclerosis - An Update. Lab Med. 2011;42(9):562-72.

9. Mulasimadhi K, Wachjudi R, dan Rahmadi A. Perubahan Pola Penyakit Pasien di Poliklinik Reumatologi Rumah Sakit dr. Hasan Sadikin Sebelum dan Sesudah Era Jaminan Kesehatan Nasional. Reumatologi Klinik Bandung. 2015.

10. Steen VD, and Medsger TA. Changes in Causes of Death in Systemic Sclerosis, 1972-2002. Ann Rheum Dis. 2007;66(7):940-4.

11. Moinzadeh P, Denton C, Abraham D, Ong V, Hunzelmann N, et al. Biomarkers for Skin Involvement and Fibrotic Activity in Scleroderma. J Eur Acad Dermatol Venereol. 2012;26(3):26776.

12. Khanna D. Diagnosis and Treatment of Systemic and Localized Scleroderma. Expert Review of Dermatology. 2011;6(3):287-302.

13. Allanore $Y$, Borderie D, Meune C, and Lemarechal H. Increased Plasma Soluble CD40 Ligand Concentrations in Systemic Sclerosis and Association with Pulmonary Arterial Hypertension and Digital Ulcers. Ann Rheum Dis.2005;64(3):481-3.

14. Agarwal SK. The Genetics of Systemic Sclerosis. Discov Med. 2010;10(51):134-43.

15. Minier T. Assesment of Disease Activity and Biomarkers in Systemic Sclerosis. 2011. 
16. Komura K, Fujimoto M, Matsushita T, Yanaba K, et al.Increased Serum Soluble CD40 Levels in Patients with Systemic Sclerosis.J Rheumatol.2007;34(2):353-8.

17. Castro SV, Jimenez SA. Biomarkers in Systemic Sclerosis. Biomark Med. 2010;4(1):133-47.

18. Minier T, Nagy Z, Balint Z, Farkas H, Radics J, et al. Construct Validity Evaluation of the European Scleroderma Study Group Activity Index, and Investigation of Possible New Disease Activity Markers in Systemic Sclerosis. Rheumatology (Oxford). 2010;49(6):1133-45.

19. Valentini G, Iudici $M$, Walker UA, Jaeger VK, Baron M, et al. The European Scleroderma Trials and Research Group (EUSTAR) Task Force for the Development of Revised Activity Criteria for Systemic Sclerosis: Derivation and Validation of a Preliminarily Revised EUSTAR Activity Index. Ann Rheum Dis. 2016;76(1): 270-276.

20. Dewi S. Uji Klinis Acak Tersamar Ganda Ekstrak Herba Ciplukan Terhadap Perbaikan Klinis Kelainan Kulit, Proses Inflamasi, Imunologi dan Fibrosis pada Pasien Scleroderma. 2017.

21. Ohtsuka T. Relation Between Elevated HighSensitivity C-Reactive Protein and AntiMitochondria Antibody in Patients with Systemic Sclerosis. J Dermatol. 2008;35(2):70-5.

22. Libby $P$, and Ridker $P$. Inflammation and Atherothrombosis from Population Biology and Bench Research to Clinical Practice. J Am Coll Cardiol. 2006;48(9):A33-46.

23. Salim S, Wachjudi R, dan Dewi S. Hubungan Kadar sCD40L dengan Nilai Forced Vital Capacity pada Penderita Sklerosis Sistemik yang Mengalami Kelainan Paru Restriktif. Bandung: Padjajaran University; 2016.

24. Yan J, Liang Y, Ma G, Zhu J, Feng Y, et al. Increased Expression of CD40 Ligand and CReactive Protein in Patients with Restenosis After Percutaneous Coronary Intervention. Therapy. 2007;4(2):175-9.

25. Perhimpunan Reumatologi Indonesia (IRA). Diagnosis dan Pengelolaan Artritis Reumatoid.Indonesia: Rekomendasi Perhimpunan Reumatologi Indonesia; 2014.

26. Perhimpunan Reumatologi Indonesia (IRA). Diagnosis dan Pengelolaan Lupus Eritematosus Sistemik. Indonesia: Rekomendasi Perhimpunan Reumatologi Indonesia; 2011.

27. Bolster M, Silver R. Clinical Features of Systemic Sclerosis. In: Hochberg M, Silman A, Smolen J, Weinblatt M, editor. Rheumatology. 5th Ed. Philadelphia: Mosby Elsevier; 2011. p. 1373-85.

28. AASLD. Hepatitis C Guidance: AASLD-IDSA Recommendations for Testing, Managing, and Treating Adults Infected With Hepatitis C Virus. Hepatology. 2015;62(3):932-54.
29. AASLD. Guidelines for Treatment of Chronic Hepatitis B.Hepatology.2016;63(1):261-83.

30. KDIGO. KDIGO 2012 Clinical Practice Guideline for the Evaluation and Management of Chronic Kidney Disease. Kidney inter., Suppl; 2013. p.1150.

31. PERKI. Pedoman Tatalaksana Sindroma Koroner Akut. Edisi ke-3. Indonesia: Perhimpunan Dokter Spesialis Kardiovaskular Indonesia; 2015.

32. Mancia G, Fagard R, Narkiewicz K, Redon J, Zanchetti A, et al. ESH/ESC Guidelines for the Management of Arterial Hypertension: The Task Force for the Management of Arterial Hypertension of the European Society of Hypertension (ESH) and of the European Society of Cardiology (ESC). J Hypertens. 2013;31(7):1281-357.

33. Rydén L, Grant PJ, Anker SD, Berne C, Cosentino F, et al. ESC Guidelines on Diabetes, Pre-Diabetes, and Cardiovascular Diseases Developed in Collaboration with the EASD. Eur Heart J. 2013;34:3035-87.

34. International Obesity Task Force. The Asia-Pacific Perspective : Redefining Obesity and Its Treatment. World Health Organization - Western Pacific Region. 2000. p.15-25

35. Elhai M, Meune C, Avouac J, Kahan A, Allanore Y. Trends in Mortality in Patients with Systemic Sclerosis Over 40 Years: a Systematic Review and Meta-Analysis of Cohort Studies. Rheumatology (Oxford). 2012; 51(6): 1017-26.

36. Mulla E, Shaffu S, Hassan W. A Comparative Study of the Difference in Clinical Manifestations and Disease Outcomes Between South Asian and Caucasian Patients with Systemic Sclerosis in a Large NHS Trust, Within the United Kingdom. Ann Rheum Dis. 2015;74 2):1128.

37. Bolster M, Silver R. Clinical Features of Systemic Sclerosis. In: Hochberg M, Silman A, Smolen J, Weinblatt M, editor. Rheumatology (Oxford). 6 ${ }^{\text {th }}$ Ed. Philadelphia: Elsevier; 2015. p.1165-73

38. Walker UA, Tyndall A, Czirjak L, Denton C, FargeBancel D, et al. Clinical Risk Assessment of Organ Manifestations in Systemic Sclerosis: a Report from the EULAR Scleroderma Trials And Research Group Database. Ann Rheum Dis. 2007;66(6):754-63.

39. Shah AA, Wigley FM. My Approach to the Treatment of Scleroderma. Mayo Clin Proc. 2013;88(4):377-93.

40. Khanna D. Assesing Disease Activity and Outcome in Systemic Sclerosis (Scleroderma). In: Hochberg M, Silman A, Smolen J, Weinblatt M, editor. Rheumatology (Oxford). $6^{\text {th }}$ Ed. Philadelphia: Elsevier; 2015. p.1153-7.

41. Alekperov RT, Baranov AA, Abaitova NE. Clinical Associations of C-Reactive Protein in Systemic Sclerosis]. Ter Arkh. 2006;78(6):30-5. 
42. Wei TQ, Kramer S, Chu VP, Hudson D, Kilgore D, et al. An Improved Automated Immunoassay for CReactive Protein on the Dimension(®) Clinical Chemistry System. Journal of Automated Methods and Management in Chemistry. 2000;22(5):12531

43. Liu X, Mayes MD, Pedroza C, Draeger HT, Gonzalez EB, Harper BE, et al. Does C-Reactive Protein Predict the Long-Term Progression of Interstitial Lung Disease and Survival in Patients With Early Systemic Sclerosis? Arthritis Care Res. 2013;65(8):1375-80.

44. Mysler E, Psioni C, Tate P, Tate G. Influence of Corticosteroids on C-Reactive Protein in Patients with Rheumatoid Arthritis. Arthritis Res Ther. 2004;6(3):57.

45. Mysler E, Psioni C, Tate P, Tate G. Influence of Corticosteroids on C-Reactive Protein in Patients with Rheumatoid Arthritis. Arthritis Res Ther. 2004;6(3):57.

46. Nagy Z, Czirjak L. Increased Levels of Amino Terminal Propeptide of Type III Procollagen are an Unfavourable Predictor of Survival in Systemic Sclerosis.Clin Exp Rheumatol.2005;23(2):165-72.

47. Khanna D. Assesing Disease Activity and Outcome in Systemic Sclerosis (Scleroderma). In: Hochberg M, Silman A, Smolen J, Weinblatt M, editor. Rheumatology (Oxford). $6^{\text {th }}$ Ed. Philadelphia: Elsevier; 2015. p.1153-7.

48. Antoniades C, Bakogiannis C, Tousoulis D, Antonopoulos AS. The CD40/CD40 Ligand System: Linking Inflammation With Atherothrombosis. J Am Coll Cardiol. 2009;54(8):669-77.

49. Fukasawa C, Kawaguchi Y, Harigai M, Sugiura T, Takagi K, et al. Increased CD40 Expression in Skin Fibroblasts from Patients with Systemic Sclerosis (SSc): Role of CD40-CD154 in the Phenotype of SSc Fibroblasts. Eur J Immunol. 2003;33(10):2792-800.

50. Postlethwaite AE, Harris LJ, Raza SH, Kodura S, Akhigbe T. Pharmacotherapy of Systemic Sclerosis. Expert Opin Pharmacother. 2010; 11(5):789-806.

51. Roumm AD, Whiteside TL, Medsger TA, Rodnan GP. Lymphocytes in the Skin of Patients with Progressive Systemic Sclerosis. Quantification, Subtyping, and Clinical Correlations. Arthritis Rheum. 2017;27(6):645-53. 